\title{
The mammography efficiency in breast cancer detection in women under 50 years of age
}

\author{
Anja Brčan, Maruša Kebe, Maša Pintar, Andrej Starc \\ University of Ljubljana, Faculty of Health Sciences, Zdravstvena pot 5, 1000 Ljubljana, Slovenia \\ anja.brcan@gmail.com; metulj.6@gmail.com; masa.pintar@gmail.com; \\ andrej.starc@zf.uni-lj.si
}

\begin{abstract}
Around the world and in Slovenia female breast cancer is the most common type of cancer. Based on risk factors the number of patients increases. In 2005 in Slovenia, there were 1111 breast cancer cases, in 2016 the number increased up to 1307 (17.6\%). In Slovenia and Europe exists a successful screening breast cancer test program, named DORA. All women between 50 and 69 years are invited in the program to perform a mammography. For women less than 50 years of age several foreign studies revealed that mammography is not the most reliable method for early breast cancer detection. The sensitivity is $61 \%$ ( $<50$ years). In relation to mammography exists a possibility for false positive results. It has been proven that $22 \%$ of all diagnoses were pre-diagnosed. This means that women have been exposed to invasive diagnostic procedure, but actually they do not need. For younger women exists a $61.3 \%$ of risk for false positive result. And for older women the risk represent $49.7 \%$. For women under 50 years the additional diagnostic methods are the ultrasound and magnetic resonance imaging, also. Descriptive method was used to critically assess Slovenian and English scientific literature. Key words: breast cancer, mammography, screening, DORA
\end{abstract}

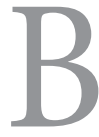

reast cancer (BRC) is the most common type of cancer in women. Incidence is higher in the developed world and lower in Africa and Asia (Edgar et al., 2013). In 2016, there was 1307 cases of newly discovered BRC in Slovenia, in 2005 the number was 1111 . The number of newly discovered diseases had increased for $17,6 \%$ (CRRS, 2017).

Risk factors for BRC are: previous BRC or BRC in family, female gender, age, previous benign breast disease, exposure to ionizing radiation, excessive 
drinking, smoking and obesity. Big impact on preventing disease have regular physical activity and healthy diet (Primic-Žakelj et al., 2003).

Screening test program is the leading measure for detecting BRC around the world for more than 40 years (Roucco, 2016). In Slovenia, there is a national screening test program for BRC since 2008, called DORA (Kadivec and Krajc, 2013). All women from 50 and 69 years of age are included in the program (Državni presejalni program za raka dojk, n. d.).

Breast tissue consists of two types: glandular tissue (milk lobules and ducts) and fatty tissue. Dense breasts are considered when milk lobules prevails and there is less fatty tissue (Mayo Clinic, 2015). Dense tissue occurs at half of women under 50 years and at one third of women over 50 years. Breast density represents a challenge for radiologists at detecting malignancy, because there is no possibility to differ individual structures or possible disease changes. Breast density is divided into 4 stages: (1) almost entirely fatty tissue, (2) scattered m areas of fibroglandular tissue, (3) heterogeneous dense tissue that could cover small masses, (4) very dense tissue - can lower mammography sensitivity (Hooley, 2017). Patients with dense breasts have more biopsies, more false positive results and are frequently exposed to radiation (Roucco, 2016). Dense breast tissue is also a risk factor for BRC (Narula, 2016).

\section{Methods}

Descriptive method was used with critical assess of professional and scientific literature in Slovene and English language. Literature was identified by using databases Medline, CINAHL, ScienceDirect and Google Scholar. Bool operators were used. Searching was limited on articles published between 2001 and 2007. Inclusion criteria for literature assess are full articles, articles related to mammography and younger women. Exclusion criteria are studies considering women over 50 years of age. We were searching using key words: breast cancer, mammography, DORA, younger women, screening, overdiagnosis, ultrasound, magnetic resonance. Statistic data was acquired on website of National Cancer Registry RS. Information about screening program DORA on website of National screening program for breast cancer. Data gathering took place from February to May 2017. 


\section{Results}

Table 1 shows an overview of 11 studies, that were reviewed.

Table 1: Overview of the studies.

Author/year

Sentis, 2010

Use of imaging diagnostic methods for BRC in young women.

\section{Used method}

Literature review

\section{Results}

Magnetic resonance imaging (MRI) has high sensitivity, it detects invasive carcinoma and also carcinoma in situ.

To assess sensitivity and specificity of combination of electrical impedance and ultrasound (US) at BRC detection in young-

Wang et al., $2010 \quad$ er women to calculate relative risk and find out if

Prospective and multicentre clinical study there is possible more precise imaging method for early BRC detection in younger women. Ways of diagnosing BRC in women with dense breast tissue.

Literature review

Massat, 2014

To compare mammog-

Ying et al., 2012 raphy and US and their combination at BRC detection.
Combination of electrical impedance and US would be suitable for BRC detection in younger women regarding to sensitivity and specificity.

The best method in women with dense breast tissue is using MRI.

US has bigger sensitivity and diagnostic accuracy than mammography, specificity is similar. Precision of diagnostic US was much better than mammography. Combination of mammography and US increases sensitivity and diagnostic accuracy.

Comparison of diagnostic efficiency of mammogra-

Shao et al., 2013 phy, US, MRI and combination of those methods at BRC detection.

To research which factors have impact on sensitivity and false positive results at mammography and MRI in women with family genetic load.

Multicentric study

Kriege et al.2006

Ineffectiveness of mam-

Brem, 2012 mography in women with dense breast tissue.
Combination of two or three methods significantly improves diagnostic sensitivity for BRC.

MRI should have been permanent screening method for BRC in women with mutation of gen BRCA1/2.

US also detects changes when mammography is negative and is successful at detecting cancer in women with dense breast tissue. 
To determine characteristic properties of BRC imaging in very young women (< 30 years), us-

An et al., 2015 ing updated BI-RADS. Further goal is to compare clinical and imaging functions in molecular type tumour in women at that age.

To compare clinical examination of breasts, mammography, US and MRI at supervising women with high risk factor for hereditary BRC and previous BRC.

Comparison of screening, mammography, tomosintesis, US, MRI and molecular imaging of breasts.

Chetlen et al., 2015
BRC imaging in very young women shows as irregular mass. Some radiological tests can be used to detect specific types of tumours.
Prospective nonrandomized multicenter study
MRI is in most cases better method than mammography, US or combination of both at screening women with high risk factor for BRC.

Literature review

Common use of tomosintesis and mammography increases specificity and decreases the number of false positive results.

Studying usage of MRI in assessment of palpable

Olsen, 2012 breast mass, where mammography and US showed Because of indicated biopsy in women with palpable breast mass is adding MRI just one. more step to cause more stress and finegative results.

Since no diagnostic method is perfect, there can also be false positive and false negative results in mammography. False positive result negatively impacts on psychological and emotional state and represents one of the stressors which can temporarily lower the quality of life (Hafslund and Nortvedt, 2009). Nelson et al. (2016) have discovered that the most false positive results in younger women (40-49 years) are because of increased breast density and it decreases with age. Normal mammography result is not a guarantee that a woman does not have cancer because some tumours cannot be detected with mammography. False negative result can cause damage because woman is not treated in the right time. Cancer can spread and metastasize to the point when treatment cannot be effective anymore (Nass et al., 2001).

Technologically enhanced methods can detect cancer earlier and where there is none (Nass et al., 2001). It is called prediagnosis, which means that disease is correctly diagnosed but will not cause damage or death to the patient (Glumac, 2012). Prediagnosis is $40-46 \%$ more common in women between 40 and 50 years of age. Consequence of prediagnosis is exaggerated intensive treatment (Roucco, 2016). 


\section{Discussion}

$\mathrm{BRC}$ is difficult to diagnose in younger women (Sentis, 2010). Wang et al. (2010) claim that there is no good strategy for early detection of BRC in younger women. Massat (2014) also claims that they misdiagnosed between 40 and 50\% of cancer in younger women which had dense breast tissue using mammography. Mammography is especially unreliable in younger women with small breast and dense tissue. The latter also represents bigger risk for false negative results (Ying et al., 2012; Shao et al., 2013; An et al., 2015). Brem (2012) states that one third of cancers are overlooked in women with dense breast tissue. Several other authors (Kriege et al., 2006; Sardanelli et al., 2011; Ying et al., 2012; An et al., 2015) are discussing about sensitivity of mammography in younger women which results in $33-61 \%$.

US is desired to use in women with breast tissue density rate 3-4 and where mammography is negative. $0.6 \%$ of BRCs are discovered with that method. Next study showed that $0.3 \%$ of BRC is detected with US, especially in those with dense breast tissue. They state that US shows especially invasive small size (<9 mm) tumours (Shao et al., 2013; Massat, 2014; Chetlen et al., 2015).

MRI is the most effective method for detecting BRC in dense breast tissue (Massat, 2014). Study shows that MRI is the best way for detecting BRC in women with BRC in family - heredity (Ying et al., 2012). Advantage of MRI is high sensitivity $(80-91 \%)$ for BRC detection but it is limited with low specificity. It is especially suitable for women with more than $20 \%$ of risk for development of BRC (Kriege, 2006; Sardanelli et al., 2011; Shao et al., 2013).

Authors state that it is crucial to use two or three diagnostic methods to achieve good sensitivity. Great reliability can be achieved if we combine mammography and US (Ying et al., 2012; Sardanelli, 2011; Shao et al., 2013). Because of dense parenchyma tissue in younger women, they advise the use of US and MRI. Both methods show excellent sensitivity compared to mammography (An et al., 2015).

\section{Conclusions}

$\mathrm{BRC}$ is the most common cancer in women. In the past, when BRC awareness was small and there was no screening programs, women had symptoms before the diagnosis. Today we thrive to detect cancer in early phase with screening programs, when there is no symptoms and there is larger possibility for successful treatment. It is mandatory to take precautions to prevent prediagnosis. Younger women have mostly dense breast tissue which interferes with mammogram interpretation which can lead to false positive or false negative results. Possible methods for detecting cancer in younger women are US and MRI with higher sensitivity compared to mammography. Mammography is currently the most used method for BRC detection. Is is important that we are well aware of its limitations. 


\section{References}

AN, Y.Y., KIM, S.H., KANG, B.J., PARK, C.S., JUNG, N.Y., KIM, J.Y., 2015. Breast cancer in very young women ( $<30$ years): Correlation of imaging of features with clinicopathological features and immunohistochemical subtypes. European journal of radiology, vol.. 84, no. 10, pp. 1894-1902.

BREM, R.M., 2012. Screening whole breast ultrasound: Screening whole breast ultrasound an opportunity to move to personalized, effective breastcancer screening. The breast journal, vol. 18, no. 6, pp. 515-516.

CHETLEN, A., MARCK, J., CHAN, T., 2016. Breast cancer sreening controversies: who, when, why, and how?. Clinical imaging, vol. 40, no. 2, pp. 279282.

CRRS REGISTER RAKA REPUBLIKE SLOVENIJE, 2017. Incidenčne mere ocena incidenčnih mer za 2016 [online]. [viewed 14 May 2017]. Avaible from: http://www.slora.si/ocena-letosnje-incidence

DRŽAVNI PRESAJALNI PROGRAM ZA RAKA DOJK, n. d. Čemu je namenjena DORA? [online]. [viewed 30 May 2017]. Avaible from: https:/dora. onko-i.si/cemu_je_namenjena_dora/index.html

EDGAR, L., GLACKIN, M., HUGHES, C. in ROGERS, K.M.A., 2013. Factors influencing participation in breast cancer screening. British journal of nursing, vol. 22, no. 7, pp. 1021-1026.

GLUMAC, N., 2012. Prediagnosticiranje. Onkologija, vol. 1, no. 1, pp. 29-32.

HAFSLUND, B. in NORTVEDT, M., 2009. Mammography screening from the perspective of quality of life: review of the literature. Scandinavian journal of theoretical science, vol. 23, no. 3, pp. 539-547.

HELLQUIST, B.N., 2014. Breast cancer screening with mammography of women 40-49 years in Sweden: doctoral thesis [online]. Umeå: Umeå University, Faculty of Medicine. [viewed 7 May 2017]. Avaible from: http://umu.diva-portal.org/smash/get/diva2:698751/FULLTEXTo1.pdf

HOOLEY, R.J., 2017. Breast Densitiy Legisation and Clinical Evidence. Radiologic clinics of North America. vol. 55, no. 3, pp. 513-526.

KADIVEC M. in KRAJC M., 2013. Presajalni program DORA za zdravje žensk. In: Matković M., eds. Pacientke z rakom dojk - Trendi in novosti: zbornik predavanj /40. Strokovni seminar, Ljubljana, 7. Junij 2013. Ljubljana: Sekcija medicinskih sester in zdravstvenih tehnikov v onkologiji pri Zbornici zdravstvene in babiške nege - Zveza strokovnih društev medicinskih sester, babic in zdravstvenih tehnikov Slovenije, pp. 14-22.

KRIEGE, M., BREKELMANS, C.T., OBDEIJN, I.M., BOETES, C., ZONDERLAND, H.M., MULLER, S.H., KOK, T., MANOLIU, R.A., BESNARD, A.P., TILANUS-LINTHORST, M.M., SEYNAEVE, C., BARTLES C.C., KAA, R., MEIJER, S., OOSTERWIJK, J.C., HOOGERBRUGGE, N., TOLLENAAR, R.A., RUTGERS, E.J., DE KONING, H.J., KLIJN, J.G., 2006. Factors affecting sensitivity and specificity of screening mammog- 
raphy and MRI in women whit inherited risk for breast cancer. Breast cancer research and treatment, vol. 100, no. 1, pp. 109-119.

MASSAT, M.B., 2014. Technology Trends: Calling in reinforcments - Women with dense breasts get help from ultrasound, molecular imaging, and MRI. Applied radiology, vol. 43, no. 9, pp. 34-38.

MAYO CLINIC, 2015. Dense breast tissue: what it means to have dense breasts [online]. [viewed 10. 5. 2017 ]. Avaible from: http://www.mayoclinic.org/tests-procedures/mammogram/in-depth/dense-breast-tissue/art-20123968

MORRIS, E., FEIG, S.A., DREXLER, M. in LEHMAN, C., 2015. Implications of overdiagnosis: impact on screening mammography practices. Population health management, vol. 18, no. 1, pp. 3-11.

NARULA, P.S., 2016. Mammographic density and the rist and detection of breast cancer. International journal od health and life science, vol. 2, no. 2, pp. 48-54.

NASS, J.S., HENDERSON, I.C. in LASHOF, J.C., 2001. Mammography and beyond: developing technologies fort he early detection of breast cancer. Washington: National academy press, pp. 15-55.

NELSON, H.D., O'MEARA, E.S., KERLIKOWSKE, K., BALCH, S. in MIGLIORETTI, D., 2016. Factors acssociated with rates of false positive and false negative results from digital mammography screening: an analysis of registry data. Annals of internal medicine, vol. 164, no. 4, pp. 226-235.

OLSEN, M.L., MORTON, M. J., STAN, D.L., PRUHTI, S., 2012. Is There a Role for Magnetic Resonance Imaging in Diagnosing Palpable Breast Masses When Mammogram and Ultrasound Are Negative?. Journal of women's health, vol. 21, no. 11, pp. 1149 - 1154.

PRIMIC-ŽAKELJ M., ARKO D., RENER M. in ŽGAJNAR J., 2003. Rak dojk v Sloveniji: Epidemiologija in presejanje. Zdravniški vestnik, vol. 72, no. 2, pp. 179-181.

RUOCCO, M.J., 2016. Improving screening mammography: perspective of a community radiologist. Applied radiology, vol. 45, no. 9, pp. 26-29.

SARDANELLI, F., PODO, F., SANTORO, F., MANOUKIAN, S., BERGONZI, S., TRECATE, G., VERGNAGHI, D., FEDERICO, M., CORTESI, L., CORCIONE, S. et. al., 2011. Multicenter surveillance of women at high genetic breast cancer risk using mammography, ultrasonography, and contrast- enhanced magnetic resonance imaging (the high berast cancer risk italian 1 study): final results. Investigative radiology, vol. 46, no. 2, pp. 94-105.

SENTIS, M., 2010. Imaging diagnosis of young women with breast cancer. Breast cancer research and treatment, vol. 123, nu. 1, pp. 1-13.

SHAO, H., LI, B., ZHANG, X., XIONG, Z., LIU, Y., TANG, G., 2013. Comparison of the diagnostic efficiency for breast cancer in Chinese women using mammography, ultrasound, MRI, and different comninations of these 
imaging modalities. Journal of $X$ - ray science and technology, vol. 21, no. 2, pp. 283-292.

WANG, T., WANG, K., YAO, Q., CHEN, J.H., LING, R., ZHANG, J.L., DONG, X.Z., FU, F., DOU, K.F., WANG, L., 2010. Prospective study on combination of electrial impedance scanning and ultrasound in estimating risk of development of breast cancer in young women. Cancer investigation, vol. 28, no. 3, pp. 295-303.

YING, X., LIN, Y., XIA, X., ZHU, Z., HE, P., 2012. A comparison of mammography and ultrasound in women with breast disease: a receiveroperating characteristic analysis. The breast journal, vol. 18, no. 2, pp. 130-138. 